\title{
Influence of Production System and Level of Dietary Soy on Bone Composition and Bone Strength in Laying Hens
}

\author{
KJ Izquierdo*, MA Parisi and JK Northcutt \\ Department of Food, Nutrition, and Packaging Sciences and Cooperative Extension Service, USA \\ *Corresponding author: KJ Izquierdo, Department of Food, Nutrition, and Packaging Sciences, and Cooperative Extension Service,Clemson, USA
}

Submission: 海 February 02, 2018; Published: 眥 March 09, 2018

\begin{abstract}
Common poultry feed ingredients such as soybean meal and its subsequent isoflavones and metabolites (daidzein \& genistein) have been found to have positive effects on bone health in estrogen deficient animals; however, the exact role these compounds play has not been well established. A field study was conducted to determine the effects of varying levels of dietary soy (high, standard or no soy) on bone characteristics in Free-range (FR) and Battery caged (BC) laying hens. At the end of an 8-week feeding trial, hens were euthanized and both femurs were removed to determine physical (weight, width, length, volume, density and breaking strength) and chemical characteristics (bone mineral content or BMC). Bird weight and feed consumption was similar in hens living in the FR system and BC system with the exception of hens in the BC system fed a soy-free diet. These hen weights were significantly lower than all other feed treatments in both housing systems, consistent with feed consumption data. Under the conditions of the present study, dietary soy supplementation in FR hens resulted in higher levels of phosphorus, calcium, and magnesium levels in femurs as compared to BC hens on a high soy diet. Within the BC production system, hens receiving soy supplementation had longer femurs that were similar in length to femurs in FR hens. Within the constraints of this study, bones in young laying hens showed minimal signs of fragility, some evidence of demineralization, and the ability to be altered with the combination of exercise and dietary soy supplementation.
\end{abstract}

Keywords: Laying hen production; Free-range chickens; Bone strength; Bone composition

\section{Introduction}

Bone fragility and osteoporosis have become major problems in the poultry industry leading to economic losses and animal welfare concerns. Osteoporosis in laying hens is characterized by the decrease in mineralized structural bone over time. The condition eventually leads to bone fragility and an increased likelihood of fractures during either the production period or depopulation [1]. While laying hens are predisposed to osteoporosis as a result of prolonged periods of egg production, battery cage systems have exacerbated the disease, causing increased incidence of fractures [2]. In advanced stages, osteoporosis can manifest itself in the form of cage-layer fatigue characterized by spontaneous bone fractures, vertebral weakness and in extreme cases even paralysis [3]. Osteoporosis in laying hens may be the result of several nutritional, environmental and genetic factors; however, physical activity and endogenous estrogen levels are two notable factors that influence the incidence of osteoporosis in commercial hens $[1,4,5]$.

Cage layer fatigue occurs almost exclusively in hens housed in battery cages [6-8]. These hens have considerably weaker bones than hens grown in high-level aviaries or free-range production systems where they have more opportunities for flight, flapping and perching [6]. A study conducted by Gregory and Wilkins [2] examined hens over the course of their entire production period and found that $29 \%$ of the hens housed in battery cages had at least one bone fracture during their lifetime. A subsequent survey found that $24 \%$ of hens from battery cages had freshly broken bones compared to broken bones in $10 \%$ of the hens in an aviary system [9]. Confinement of birds in cages where they have limited mobility and negligible physical activity contributes to the manifestation of disuse atrophy and osteoporosis [1]

Another factor that affects the incidence of osteoporosis in laying hens is endogenous estrogen which largely controls the formation of medullary bone [4]. Medullary bone (MB), common in long-bones, is a non-structural type of woven bone exclusive to female egg-laying birds that can be resorbed 10-15 times faster than structural bone and provides the necessary calcium (Ca) for egg shell formation [10]. Shortly before hens enter lay, circulating plasma 17- $\beta$ estradiol increases triggering follicular maturation and medullary bone formation [1]. During the laying period, structural bone formation ceases and is continuously resorbed to supply calcium for medullary bone synthesis causing skeleton 
fragility and increasing the chance of fractures [6]. Decreased 17- $\beta$ estradiol circulation signals a decline in egg production and causes medullary bone formation to cease [1]. As estradiol levels decline, formation of structural bone recommences, and is evident by the appearance of a layer of structural bone deposited on top of the existing medullary bone [11]. This homeostatic mechanism is normal in all laying hens enabling them to lay in clutches with the follow-up incubation giving them time to regenerate structural bone [1]. However, commercial laying hens are typically selected for production capacity, and prolonged lay leads to bone fragility and eventual osteoporosis [4].

Recent research has begun to investigate the effects of soybean isoflavones on avian performance, hatchability, egg quality, blood parameters and organ development [12-16]. Structurally similar to estrogen, isoflavones and their subsequent metabolites (daidzein and genistein) have been found to exhibit estrogenic behavior by binding to estrogen receptors (ER's) [17]. Based on levels of endogenous estrogen, the effects of isoflavones can be classified as positive (amplifying the effects of estrogen), or negative (suppressing and down-regulating estrogen) [18]. Reports have suggested that soybean isoflavones may reduce the risk of osteoporosis [12]. In avian species, few studies have examined the impact of high-doses of soybean isoflavones on bone development and maintenance. Thus, the purpose of this field trial was to examine the effects of dietary isoflavone supplementation (in the form of soy germ) on the physical and chemical properties of femurs harvested from laying hens that were reared in either battery cages (BC) or free range (FR) production systems.

\section{Materials and Methods}

This research project was reviewed and approved by the Clemson University Institutional Animal Care and Use Committee (IACUC) prior to the procurement of chicks (Institutional Animal Care and Use Number UAP 2011-008). Researchers completed the Animal Care and Use Series-Live Vertebrate Animals, through the Clemson University IACUC training program. The series meets USDA and Office of Laboratory Animal Welfare requirements for training in the humane care and use of animals. It covers general principles of the ethical care and use of animals in research. These institutional and national guidelines were followed for the care and use of the laying hens used in this study.

\section{Housing}

Eighty-four, 2 day old, Bovan Brown chicks from a commercial

Table 1: Diet fed to laying hens after 20 wk-of-age. hatchery were transferred to the University Poultry Production Center. Chicks were maintained in 6 indoor floor pens under brooders and on pine shavings in groups of 14 chickens per pen and given ad libitum access to feed and water. At 16 weeks of age, pullets from three of the pens were moved to a FR housing system and pullets in the remaining three pens were moved into the $\mathrm{BC}$ housing system.

Caged layers were housed in two banks of BC in an indoor poultry house. Banks were 3 cages high, 4 cages per level, and 2 cages wide. Each BC had 61 X 61 X $41 \mathrm{~cm}(0.15 \mathrm{~m} 3)$ of space. Sets of 3 or 4 pullets from a single floor pen were placed into individual BC along a single bank row. A total of three rows, one row from each floor pen, were staggered among the 2 banks to avoid cross-over of feed or feces from one group to another during the study. Cages had wire mesh flooring and were equipped with feed troughs and nipple drinkers. Egg collection troughs with wire dividers were attached to the front of the cages to preclude eggs from one cage mixing with eggs from another cage.

The FR house was partitioned into three $1.5 \times 3 \mathrm{~m}(4.5 \mathrm{~m} 2)$ indoor pens, each with access to a separate $7.6 \times 13.7 \mathrm{~m}(104.5 \mathrm{~m} 2)$ outdoor range. Chain link fencing, an outside electric wire and overhead nylon netting were used to prevent entrance by predators. A light-weight shading tarp was spread over $1 / 3$ of the overhead netting to supply shade for each range area. Grass was mowed short in each range and surrounding areas prior to introducing the pullets to the FR system. The three indoor pens of the range house were separated by fencing and were equipped with 9 nest boxes each. Nest boxes contained pine shavings and were accompanied by wooden perches. Each pen contained a separate waterer and feeder and the floor was covered with pine shavings bedding.

\section{Diets}

All diets met the National Research Council nutrient requirements for poultry [19]. During the grow-out period (2 days to 20 weeks of age), parallel diets for FR and BC hens of standard $25 \%$ soy (SS) formulations were used. FR diets were plant-based while the BC diets included animal sources of fat and protein to mimic typical commercial diets in these production systems. Birds received starter feed crumbles consistent with their pen's housing system assignments until 18 weeks of age when starter feeds were substituted with layer feeds. Standard soy layer feeds were fed from 18-20 weeks of age. When hens turned 20 weeks of age, all hens were fed a washout diet of either the BC or FR soy free diets. At 21 weeks, hens began 3 weeks of their assigned treatment diets.

\begin{tabular}{|c|c|c|c|c|}
\hline Ingredient (\% by volume) & Battery Cage (BC) & Free-Range (FR) & & \\
\hline & Standard Soy1 BCSS & Soy-Free2 BCSF & Standard Soy1 FRSS & Soy-Free1 FRSF \\
\hline Corn \% & 56.4 & 58.8 & 56.4 & 18.2 \\
\hline Soybean meal \% & 25 & 0 & 25 & 0 \\
\hline Poultry meal \% & 0 & 19.67 & 0 & 0 \\
\hline Poultry fat \% & 4.75 & 0 & 4.75 & 0 \\
\hline Whole soybeans\% & 0 & 0 & 0 & 0 \\
\hline
\end{tabular}




\begin{tabular}{|c|c|c|c|c|}
\hline Fish meal \% & 0 & 0 & 0 & 9.6 \\
\hline Wheat middlings \% & 0 & 0 & 0 & 12 \\
\hline Alfalfa meal \% & 0 & 0 & & 3.6 \\
\hline Distillers dried grains \% & 0 & 19.6 & 0 & 0 \\
\hline Calcium \% & 2.25 & 0 & 2.25 & 0 \\
\hline Limestone \% & 10.75 & 0.68 & 10.75 & 6.2 \\
\hline Methionine \% & 0.2 & 0.2 & 0.2 & 0 \\
\hline Lysine $\%$ & 0 & 0.45 & 0 & 0 \\
\hline Salt \% & 0.35 & 0.3 & 0.35 & 0 \\
\hline Vitamin mix \% & 0.25 & 0.23 & 0.25 & 0 \\
\hline Mineral mix \% & 0.05 & 0.07 & 0.05 & 1.23 \\
\hline Field peas $\%$ & 0 & 0 & 0 & 27.1 \\
\hline Oats $\%$ & 0 & 0 & 0 & 12 \\
\hline Sunflower oil \% & 0 & 0 & 0 & 0.38 \\
\hline Flaxseed \% & 0 & 0 & 0 & 2.4 \\
\hline Kelp \% & 0 & 0 & 0 & 0.48 \\
\hline Diamond V XP Green4 \% & 0 & 0 & & 3.6 \\
\hline Poultry Nutribalancer5 \% & 0 & 0 & 0 & 2.88 \\
\hline
\end{tabular}

${ }^{1}$ Commercial layer diets for laying hen.

${ }^{2}$ Formulated from animal proteins and is not commercially available.

${ }^{3}$ BCSS=Battery Cage Standard Soy Feed; BCSE=Battery Cage Soy Enhanced Feed; BCSF=Battery Cage Soy Free Feed; FRSS=FreeRange Standard Soy Feed; FRSE=Free-Range Soy Enhanced Feed; FRSF=Free-Range Soy Free Feed

${ }^{4}$ Trace mineral colloidal silicate of nearly 50 mineral compounds approved by the Organic Material Review Institution

5Diamond V Mills, Cedar Rapids, IA

6Countryside Organics, Waynesboro, VA

Layer feeds (Table 1) included: 1) FR standard soy feed (FRSS) which contained $18 \%$ crude protein with 2,750kcal/kg ME; 2) FR soy free feed (FRSF) containing 19\% crude protein with $2,684 \mathrm{kcal} /$ kg ME; 3) BC standard soy feed (BCSS) containing 19\% crude protein with $2,750 \mathrm{kcal} / \mathrm{kg}$ ME and 4) BC soy free feed (BCSF) which contained $18 \%$ crude protein with $2,860 \mathrm{kcal} / \mathrm{kg}$ ME. Two soy enhanced feeds were formulated - one for the FR hens and

one for the $\mathrm{BC}$ hens. These were created by adding 5 grams of soygerm/100 grams of feed to the 25\% standard FR feed and BC feed. Soy germ was procured in a bulk shipment and mixed with the SS feeds in the feed mixing room at the University of Georgia's (UGA) Poultry Research Farm facility in Athens, Georgia. All feeds were mixed on the same day and in the total amount needed for the duplicate trials.

Table 2: Proximate composition and mineral analyses of diets prior to feeding to laying hens and reported on a dry weight basis 1

\begin{tabular}{|c|c|c|c|c|c|c|}
\hline \multirow[b]{2}{*}{ Composition } & \multicolumn{6}{|c|}{ Hen Diets ${ }^{2}$} \\
\hline & BCSS & BCSE & BCSF & FRSS & FRSE & FRSF \\
\hline Crude Protein (\%) & 18.8 & 19.7 & 18.4 & 18.6 & 19 & 18.1 \\
\hline Fat (\%) & 2.5 & 2 & 7.7 & 3.3 & 3.2 & 3 \\
\hline Moisture (\%) & 10.7 & 10.2 & 10.1 & 10.3 & 9.7 & 11.2 \\
\hline Dry matter (\%) & 89.3 & 89.8 & 89.9 & 89.7 & 90.3 & 88.8 \\
\hline $\mathrm{P}(\%)$ & 0.72 & 0.77 & 1.49 & 0.79 & 0.83 & 1.09 \\
\hline $\mathrm{Ca}(\%)$ & 3.3 & 3.2 & 6.44 & 4.25 & 3.33 & 4.9 \\
\hline $\mathrm{Ca} / \mathrm{P}$ & 4.61 & 4.16 & 4.32 & 5.37 & 4.01 & 4.48 \\
\hline $\operatorname{Mg}(\%)$ & 0.19 & 0.2 & 0.22 & 0.35 & 0.34 & 0.24 \\
\hline K (\%) & 0.9 & 0.9 & 0.54 & 1.14 & 1.13 & 0.71 \\
\hline $\mathrm{S}(\%)$ & 0.24 & 0.23 & 0.33 & 0.28 & 0.27 & 0.26 \\
\hline Zn (ppm) & 180 & 138 & 136 & 172 & 134 & 194 \\
\hline
\end{tabular}




\begin{tabular}{|c|c|c|c|c|c|c|}
\hline $\mathrm{Cu}(\mathrm{ppm})$ & 19 & 22 & 16 & 20 & 14 & 12 \\
\hline $\mathrm{Mn}(\mathrm{ppm})$ & 110 & 124 & 135 & 161 & 152 & 140 \\
\hline $\mathrm{Fe}(\mathrm{ppm})$ & 271 & 267 & 162 & 174 & 159 & 615 \\
\hline
\end{tabular}

${ }^{1}$ Standard mineral analyses includes: phosphorus $(\mathrm{P})$, potassium $(\mathrm{K})$, calcium $(\mathrm{Ca})$, magnesium $(\mathrm{Mg})$, sulfur $(\mathrm{S})$, zinc $(\mathrm{Zn})$, copper $(\mathrm{Cu})$, manganese $(\mathrm{Mn})$ and iron $(\mathrm{Fe})$.

${ }^{2}$ FRSS=Free-Range Standard Soy Feed; FRSE=Free-Range Soy Enhanced Feed; FRSF=Free-Range Soy Free Feed; BCSS=Battery Cage Standard Soy Feed; BCSE=Battery Cage Soy Enhanced Feed; BCSF=Battery Cage Soy Free Feed.

Prior to initiating the treatments, layer feeds were tested for proximate composition at the University Agriculture Service Laboratory. Samples were analyzed for mineral content, crude protein and total fat and feed composition was adjusted as needed with limestone to ensure comparable calcium-phosphorus ratios (Table 2). Standard mineral profile (phosphorus, potassium, calcium, magnesium, sulfur, zinc, copper, manganese, and iron) was performed by dry ashing the samples and determining mineral content using inductively coupled plasma-mass spectrometry [20]. Crude protein was calculated as percentage of total nitrogen based on dry weight measured with a LECO FP528 Nitrogen Combustion Analyzer (AOAC Official Method 990.03). Percent fat was determined using a traditional Soxhlet extraction method with diethyl ether (AOAC Official Method 920.39).

At the beginning of each 3-week trial, all hens were fed the soyfree (control) diets (BCSF, FRSF) for one week to serve as a washout period. Hens were then assigned to one of three diets within each housing system: control diet (soy free), standard soy (25\% soy) or soy-enhanced ( $30 \%$ soy) diet. The three diets were used in the 2 different production systems for a total of six treatments (BCSF, BCSS, BCSE or FRSF, FRSS, FRSE). The 3-week trial was duplicated after another one week, soy-free diet washout period.

\section{Bone parameters}

At the end of the feeding study, 18 hens ( 9 from each production system) were euthanized by cervical dislocation. Hens were chosen at random within the two production systems to include 3 hens from each soy treatment (SF, SS and SE).

Both femurs were removed from each carcass, cleaned of adhering tissue and stored at $4.4^{\circ} \mathrm{C}$ for less than $24 \mathrm{~h}$. Femur length was measured from medial condyle to the greater trochanter using digital calipers and recorded to the nearest 100th decimal place. Similarly, width measurements were taken at the calculated Results and Discussion

Table 3: Laying hen body weight $(\mathrm{Kg})$ and feed consumption $(\mathrm{Kg})$ for Battery Cage and Free Range production systems and diets ${ }^{1}$

\begin{tabular}{|c|c|c|c|c|c|c|}
\hline & \multicolumn{3}{|c|}{ FR Diets $^{2}$} & \multicolumn{3}{|c|}{ BC Diets ${ }^{2}$} \\
\hline & \multicolumn{3}{|c|}{ Age 23 (Treatment Week 3, Cohort 1) } & \multicolumn{3}{|c|}{ Age 23 (Treatment Week 3, Cohort 1) } \\
\hline & FRSS & FRSE & FRSF & BCSS & BCSE & BCSF \\
\hline Weight $^{3}$ & \multirow{2}{*}{$1.74^{\mathrm{a}}$} & \multirow{2}{*}{$1.76^{\mathrm{a}}$} & \multirow{2}{*}{$1.77^{\mathrm{a}}$} & \multirow{2}{*}{$1.77^{\mathrm{a}}$} & \multirow{2}{*}{$1.72^{\mathrm{a}}$} & \multirow{2}{*}{$1.56^{\mathrm{b}}$} \\
\hline$(\mathrm{Kg})$ & & & & & & \\
\hline \multirow[t]{2}{*}{$\begin{array}{c}\text { Weekly Feed } \\
\text { Consumption }^{4}(\mathrm{Kg})\end{array}$} & $1.45^{\mathrm{a}}$ & $1.45^{\mathrm{a}}$ & $1.11^{\mathrm{a}}$ & $1.11^{\mathrm{a}}$ & $0.92^{\mathrm{a}}$ & $0.83^{\mathrm{b}}$ \\
\hline & \multicolumn{3}{|c|}{ Age 24 (treatment week 3 , cohort 2 ) } & \multicolumn{3}{|c|}{ Age 27 (treatment week 3, cohort 2) } \\
\hline
\end{tabular}




\begin{tabular}{|c|c|c|c|c|c|c|}
\hline Weight $^{3}$ & \multirow{2}{*}{$1.88^{\mathrm{a}}$} & \multirow{2}{*}{$1.89^{\mathrm{a}}$} & \multirow{2}{*}{$1.87^{\mathrm{a}}$} & \multirow{2}{*}{$1.83^{\mathrm{a}}$} & \multirow{2}{*}{$1.77^{\mathrm{a}}$} & \multirow{2}{*}{$1.56^{\mathrm{b}}$} \\
\hline$(\mathrm{Kg})$ & & & & & & \\
\hline $\begin{array}{c}\text { Weekly Feed } \\
\text { Consumption4 (Kg) }\end{array}$ & $1.45^{\mathrm{a}}$ & $1.47^{\mathrm{a}}$ & $0.93^{\mathrm{a}}$ & $1.08^{a}$ & $1.10^{\mathrm{a}}$ & $0.78^{\mathrm{b}}$ \\
\hline
\end{tabular}

a-bMeans in the same row without common superscripts are significantly different at $\mathrm{P} \leq 0.05$

$1 \mathrm{~N}=14$ laying hens.

2FRSS=Free-Range Standard Soy Feed; FRSE=Free-Range Soy Enhanced Feed; FRSF=Free-Range Soy Free Feed; BCSS=Battery Cage Standard Soy Feed; BCSE=Battery Cage Soy Enhanced Feed; BCSF=Battery Cage Soy Free Feed

3Mean body weight for hens assigned to treatment group.

4Average feed consumption per hen per week in kg during the $7 \mathrm{~d}$ period after the reporte age.

The present study was undertaken to determine the influence of dietary soy on growth and bone maintenance of laying hens reared in two different production systems. Hens were moved to either BC or FR production systems 4 weeks before the first feeding trial was initiated for acclimatization. This was important as the trials were conducted over the summer months (July and August) in the Southeast in the U.S. Average environmental temperatures (FR) during the two feeding trials ranged from 22.2 to $38.3^{\circ} \mathrm{C}$, while the environmental conditions within the house where the $\mathrm{BC}$ were located had temperatures ranging from 18.3 to $36.7^{\circ} \mathrm{C}$ during the two trials. No difference was observed in hen body weight between the two production systems during the two washout periods (age 20 and $24 \mathrm{wk}$ ); however, body weight for hens on the BCSF treatment were significantly lower by 10 to $21 \%$ than the body weight for BCSS, BCSE, FRSS, FRSE, and FRSF at week 3 of both cohorts (Table 3). Feed consumption was also significantly lower for hens on the BCSF treatment as compared to feed consumption for hens on all other diets. These data are similar to that reported by Lu et al. [12] who evaluated the effect of feeding daidzein to cage layers at 10

and 20 times the standard level. Lu and coworkers [12] found no difference in feed intake, feed conversion and mortality for hens fed control diets and hens fed high levels of daidzein. These researchers did not test a soy-free or daidzein-free diet. In the present study, the reduced consumption of the BCSF diet could have been because the hens simply did not prefer the taste of the uniquely formulated diets in the present study [26].

Femurs were evaluated for physical, chemical and mechanical properties. Femurs from hens varied in weight by approximately $1.68 \mathrm{~g}$ with the largest femurs (11.6 and $10.65 \mathrm{~g}$ ) originating from hens fed SE diets (Table 4). Within a diet treatment, production system had no effect on femur length. Silversides et al. [5] studied tibia bones in laying hens and reported that hens held in floor pens had tibia bones that weighed the same as the tibias harvested from hens held in cages. These researchers postulated that leg bones for hens in floor pens or in cages were similar because caged layers spent the majority of their time standing (load-bearing), while floor-pen hens had room to exercise - both activities having similar effects on leg bones [5].

Table 4: Effect of production system and diet on the physical properties of laying hen femurs post-slaughter ${ }^{1,2}$

\begin{tabular}{|c|c|c|c|c|c|c|}
\hline \multirow[t]{2}{*}{ Production System } & \multicolumn{6}{|c|}{ Bone Parameters } \\
\hline & Diet $^{3}$ & Weight (g) & Width (mm) & Length (mm) & Volume $\left(\mathrm{cm}^{3}\right)$ & Density $\left(\mathrm{g} / \mathrm{cm}^{3}\right)$ \\
\hline & SE & $10.6^{\mathrm{ab}} \pm 0.3$ & $8.14 \pm 0.04$ & $86.6^{\mathrm{ab}} \pm 0.4$ & $8.1 \pm 0.2$ & $1.31 \pm 0.02$ \\
\hline & SS & $9.92^{\mathrm{b}} \pm 0.4$ & $8.1 \pm 0.08$ & $84.4^{\mathrm{b}} \pm 1.2$ & $7.3 \pm 0.3$ & $1.35 \pm 0.01$ \\
\hline \multirow[t]{3}{*}{ Battery Cage } & SF & $10.2^{\mathrm{b}} \pm 0.3$ & $8.1 \pm 0.14$ & $84.5^{\mathrm{b}} \pm 0.8$ & $7.7 \pm 0.3$ & $1.34 \pm 0.04$ \\
\hline & SE & $11.6^{a} \pm 0.4$ & $8.1 \pm 0.3$ & $89.9^{\mathrm{a}} \pm 1.2$ & $8.2 \pm 0.3$ & $1.42 \pm 0.01$ \\
\hline & SS & $10.2^{\mathrm{b}} \pm 0.1$ & $8.1 \pm 0.16$ & $87.1^{\mathrm{ab}} \pm 0.7$ & $7.7 \pm 0.2$ & $1.34 \pm 0.03$ \\
\hline Free Range & SF & $10.1^{\mathrm{b}} \pm 0.2$ & $8.2 \pm 0.1$ & $86.3^{\mathrm{ab}} \pm 0.8$ & $7.5 \pm 0.3$ & $1.35 \pm 0.03$ \\
\hline
\end{tabular}

a-bMeans+standard error in a column without common superscripts are significantly different at $\mathrm{P}<0.05$.

${ }^{1} \mathrm{n}=6$ samples per production system and diet combination.

${ }^{2}$ Laying hens approximately 29 weeks of age

${ }^{3} \mathrm{SE}$ represents standard soy feed content (25\%) with added soy germ in the amount of $5 \mathrm{~g}$ soy-germ/100 grams feed; SS indicates standard soy diets with $25 \%$ soy content; SF represents a diet that did not contain soy.

Length of femurs from hens ranged from $89.9 \mathrm{~mm}$ to $84.4 \mathrm{~mm}$ (Table 4). Femurs from BC hens fed an SE diet $(86.6 \mathrm{~mm})$ were similar in length to all of the femurs collected from FR hens (89.9. 87.1 , and $86.3 \mathrm{~mm}$ ). This suggest that feeding an SE diet to $\mathrm{BC}$ hens will lead to the development of femurs with similar length to those found in FR hens. Femurs from BC and FR hens had similar femur bone width, volume, and density (Table 4; P > 0.05).
Bone strength and bone mineralization were measured on femurs to determine if there was any evidence of osteoporosis in laying hens. Femur bone strength as measured by force-tofracture varied widely (217.4 $\mathrm{N}$ to $304.7 \mathrm{~N}$ ) and showed no distinct difference due to hen diet or production system (data not shown). Indiscernible patterns in bone strength data may stem from the young age of the hens and the genetics of the strain used (Bovan Brown), a typical free-range bird. Previous research has 
demonstrated that bone strength of femurs harvested from hens housed in conventional battery cages was significantly lower (21.92kgf or $215 \mathrm{~N}$ ) than bone strength of femurs harvested from hens in colony cages modified to allow increased movement (approximately 27-30kg for 265-290 N) [3]. Values in the present study are similar to those previously reported, but wide variations in the data suggest that more information is need to draw a similar conclusion.

Table 5: Effect of production system and diet on bone mineral content (BMC) of femurs from laying hens post-slaughter ${ }^{1,2}$

\begin{tabular}{|c|c|c|c|c|c|}
\hline \multirow[t]{2}{*}{ Production System } & \multicolumn{5}{|c|}{ Bone Mineral Content } \\
\hline & Diet3 & $\mathbf{P}$ & $\mathrm{Ca}$ & Mg & $\mathrm{Ca} / \mathrm{P}$ \\
\hline & & $(\%)$ & $(\%)$ & $(\%)$ & \\
\hline & SE & $7.17 \mathrm{c} \pm(0.45)$ & $15.3 \mathrm{c} \pm(0.98)$ & $0.227 c \pm(0.016)$ & $2.14 \mathrm{c} \pm(0.006)$ \\
\hline & SS & $7.97 \mathrm{ab} \pm(0.17)$ & $16.9 \mathrm{ab} \pm(0.38)$ & $0.263 b \pm(0.006)$ & $2.12 \mathrm{~cd} \pm(0.006)$ \\
\hline \multirow[t]{3}{*}{ Battery Cage } & SF & $7.87 \mathrm{ab} \pm(0.22)$ & $16.4 \mathrm{bc} \pm(0.50)$ & $0.272 b \pm(0.008)$ & $2.09 \mathrm{~d} \pm(0.015)$ \\
\hline & SE & $8.12 \mathrm{a} \pm(0.14)$ & $18.0 \mathrm{a} \pm(0.35)$ & $0.313 a \pm(0.007)$ & $2.22 \mathrm{~b} \pm(0.020)$ \\
\hline & SS & $7.56 \mathrm{abc} \pm(0.19)$ & $17.2 \mathrm{ab} \pm(0.41)$ & $0.283 \mathrm{~b} \pm(0.009)$ & $2.27 a \pm(0.014)$ \\
\hline Free Range & SF & $7.40 \mathrm{bc} \pm(0.18)$ & $17.0 \mathrm{ab} \pm(0.42)$ & $0.256 b c \pm(0.009)$ & $2.30 \mathrm{a} \pm(0.009)$ \\
\hline
\end{tabular}

a-d Means with standard error in parenthesis in a column without common superscripts are significantly different at $\mathrm{P}<0.05$.

${ }^{1} \mathrm{n}=6$ samples / group

${ }^{2}$ Laying hens 29 weeks of age

${ }^{3} \mathrm{SE}$ represents standard soy feed content with added soy germ in the amount of $5 \mathrm{~g}$ soy-germ/100 grams feed; SS indicates standard soy diets with $25 \%$ soy content; SF represents soy-free diet

${ }^{4} \mathrm{NS}=$ Not significant at $\mathrm{P}>.05$

${ }^{5}$ Probability value for General Linear Model of SAS

(Table 5) shows the bone mineral composition (phosphorus, calcium, magnesium, copper) of femurs from hens grown in either BC or FR production systems and fed diets of SE, SS and SF. Phosphorus (P) levels ranged from $7.17 \%$ to $8.12 \%$. Numerically, the highest $\mathrm{P}$ content $(8.12 \%)$ was found in femurs from FR hens on SE diet, but this was statistically similar to P levels in femurs from hens (both FR and $\mathrm{BC}$ ) on SS (7.56\% and 7.97\%, respectively) and $\mathrm{BC}$ hens on SF diets $(7.87 \%)$. Calcium (Ca) content of femurs in the current study ranged from $15.3 \%$ to $18.0 \%$. Dickerson [27] found that Ca content in the bones of hens increase with hen age and reported a $15.1 \%$ Ca content of femurs from 15-wk old pullets compared to $18 \%$ Ca in 27-42 wk old hens. Findings in the present study of Ca content in femurs therefore are consistent with Dickerson [27] and other past research on Ca content in bones of young hens [27-29]. Magnesium (Mg) levels were highest in femurs from FR hens fed SE $(0.313 \%)$ with lowest values in femurs from BC hens on the same diet. This suggest that $\mathrm{Mg}$ levels in femurs were influenced more by the production system than the diet. Highest levels of copper (Cu) in femurs were found with FR hens as compared to BC hens, where levels were consistent "not detectable."

Although minimized, some of the differences in the bone mineral composition could have been caused by consumption of weeds and grass by FR hens. Crozier et al. [30] and Sturgeon et al. [31] demonstrated that tall fescue and Bermuda grass can be a significant and suitable forage source of $\mathrm{Ca}, \mathrm{Mg}$, and $\mathrm{Cu}$ in mature horses, although these researchers did not evaluate mineral bone deposition.

Under the conditions of the present study, soy supplementation appeared to act synergistically with the FR production system to increase femur $\mathrm{P}, \mathrm{Ca}$, and $\mathrm{Mg}$ levels above those levels found with $\mathrm{BC}$ hens on SE diets. Within the BC system, SE improved the length of femurs but had no other discernible impact. This suggests that high levels of soy supplementation may work in concert with mechanical loading to slow bone loss in young laying hens reared in FR production systems. Further studies need to be conducted to determine how soy germ supplementation affects laying hens as they age and its relationship to bone strength.

\section{Acknowledgements}

The authors would like to acknowledge the help and poultry expertise of University of Georgia poultry nutritionist, Nicholas M. Dale, and the Poultry Research Center Supervisor, Christopher A. McKenzie. Additionally, the authors gratefully acknowledge expert technical assistance by Randy Koch of Texture Technologies and Carol Foster-Mosley and Karen Tankersley of Clemson University Morgan Poultry Farm.

\section{Referances}

1. Whitehead CC, Fleming RH (2000) Osteoporosis in cage layers. Poult Sci 79(7): 1033-1041.

2. Gregory NG, Wilkins LJ (1989) Broken bones in domestic fowl: Handling and processing damage in end-of-lay battery hens. Br Poult Sci 30(3): 555-562.

3. Jendral MJ, Korver DR, Church JS, Feddes JJ (2008) Bone mineral density and breaking strength of white leghorns housed in conventional, modified, and commercially available colony battery cages. Poult Sci 87(5):828-837

4. Beck MM, Hansen KK (2004) Role of estrogen in avian osteoporosis. Poult Sci 83(2): 200-206.

5. Silversides FG, Singh R, Singh KM, Cheng KM, Korver DR (2012) Comparison of bones of 4 strains of laying hens kept in conventional cages and floor pens. Poult Sci 91(1): 1-7.

6. Webster AB (2004) Welfare implications of avian osteoporosis. Poult Sci 83(2):184-192 
7. Couch JR (1955) Cage layer fatigue. Feed Age. 5:55-57.

8. Knowles TG, Wilkins LJ (1998) The Problem of broken bones during the handling of laying hens-A review. Poult Sci 77(12): 1798-1802.

9. Gregory NG, Wilkins LJ (1990) Broken bones in chickens: Effects of stunning and processing in broilers. British Poultry Science 31(1): 5358.

10. Dacke CG, Arkle S, Cook DJ, Wormstone IM, Jones S, et al. (1993) Medullary bone and avian calcium regulation Journal of Experimental Biology 184: 63-88.

11. Whitehead CC (2004) Overview of bone biology in the egg-laying hen Poult. Sci 83(2): 193-199.

12. Lu J, Qu L, Shen MM, Li SM, Dou TC, et al. (2017) Safety evaluation of daidzein in laying hens: Effects on laying performance, hatchability, egg quality, clinical blood parameters, and organ development. Poult Sci 96(7):2098-2103.

13. Zhao R, Wang Y, Zhou Y, Ni Y, Lu L, et al. (2004) Dietary daidzein influences laying performance of ducks (Anas platyrhynchos) and early post-hatch growth of their hatchlings by modulating gene expression. Comp Biochem Physiol A Mol Integr Physiol 138(4): 459-466.

14. Zhao RQ, Zhou YC, Ni YD, Lu LZ, Tao ZR, et al. (2005) Effect of daidzein on egg-laying performance in Shaoxing duck bredders during different stages of the egg production cycle. Br Poult Sci 46(2): 175-181.

15. Ni Y, Zhu Q, Zhou Z, Grossman R, Chen J, et al. (2007) Effect of dietary daidzein on egg production, shell quality, and gene expression of ER- $\alpha$ GH-R and IGF-IR in shell glands of laying hens J Agric Food Chem 55(17): 6997-7001.

16. Sahin N, Onderci M, Balci TA, Cikim G, Sahin K, et al. (2007) The effect of soy isoflavones on egg quality and bone mineralization during the lay laying period of quail. Journal British Poultry Science 48(3): 363-369.

17. Cassidy A (2003) Potential risks and benefits of phytoestrogen-rich diets. Int J Vitam Nutr Res 73(2): 120-126.

18. Setchell KDR, Cassidy A (1999) Dietary isoflavones: biological effects and relevance to human health. The Journal of Nutrition 129(3): 758767.

19. National Research Council (1994) Nutrient requirements of poultry: ninth re. ed. National Academy Press, Washington, USA.

20. US Environmental Protection Agency (1994) Determination of trace elements in waters and wastes by inductively coupled plasma-mass spectrometry, Method 200.8 U.S. Environmental Protection Agency, Environmental Monitoring Systems Lab, Cincinnati, Ohio.

21. Turner KA, Lilburn MS (1992) The effect of early protein restriction (zero to eight weeks) on skeletal development in turkey toms from two to eighteen weeks. Poult Sci 71(10): 1680-1686.

22. Applegate TJ, Lillburn MS (2002) Growth of femur and tibia of a commercial broiler line. Poultry Science 81(9): 1289-1294.

23. Reddish JM, Lillburn MS (2004) A comparison of growth and development patterns in diverse genotypes of broilers and 2. Pullet growth Poult Sci 83(7): 1072-1076.

24. Cheng TK, Coon CN (1990) Sensitivity of various bone parameters of laying hens to different daily calcium intakes. Poult Sci 69(12): 713-720.

25. SAS (2000) SAS/STAT User's Guide. Release 8.3 ed SAS Institute Inc., Cary, USA.

26. Moran ET (1982) Comparative Nutrition of Fowl and Swine: the Gastrointestinal Systems. Office for Educational Practice, Guelph, Ontario, USA.

27. Dickerson JWT (1962) The effect of development on the composition of a long bone of the pig, rat, and fowl. Biochem J 82 (1): 47-55.

28. Taylor TG Moore JH, Hertelendy F (1960) Variations in the mineral composition fo individual bones of the skeleton of the domestic fowl. Brit J Nutr 14: 49-57.

29. Field RA, Riley ML, Mello FC, Corbridge MH, Kotula AW (1974) Bone composition in cattle, pigs, sheep, and poultry. J Anim Sci 39 (3); 493499.

30. Crozier JA, Allen VG, Jack NE, Fontenot JP, Cochran MA (1997) Digestibility, apparent mineral absorption, and voluntary intake by horses fed alfalfa, tall fescue, and caucasion bluestem. J Anim Sci 75(6):1651-1658.

31. Sturgeon LS, Baker LA, Pipkin JL, Haliburton JC, Chirase NK (2000) The digestibility and mineral availability of Matua, Bermuda grass, and alfalfa hay in mature horses. J of Equine Vet Sci 20(1):45-48.
Creative Commons Attribution 4.0 International License

For possible submissions Click Here

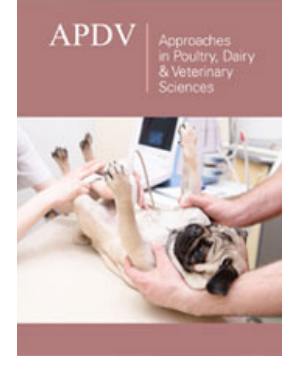

Approaches in Poultry, Dairy \& Veterinary Sciences

Benefits of Publishing with us

- High-level peer review and editorial services

- Freely accessible online immediately upon publication

- Authors retain the copyright to their work

- Licensing it under a Creative Commons license

- Visibility through different online platforms 